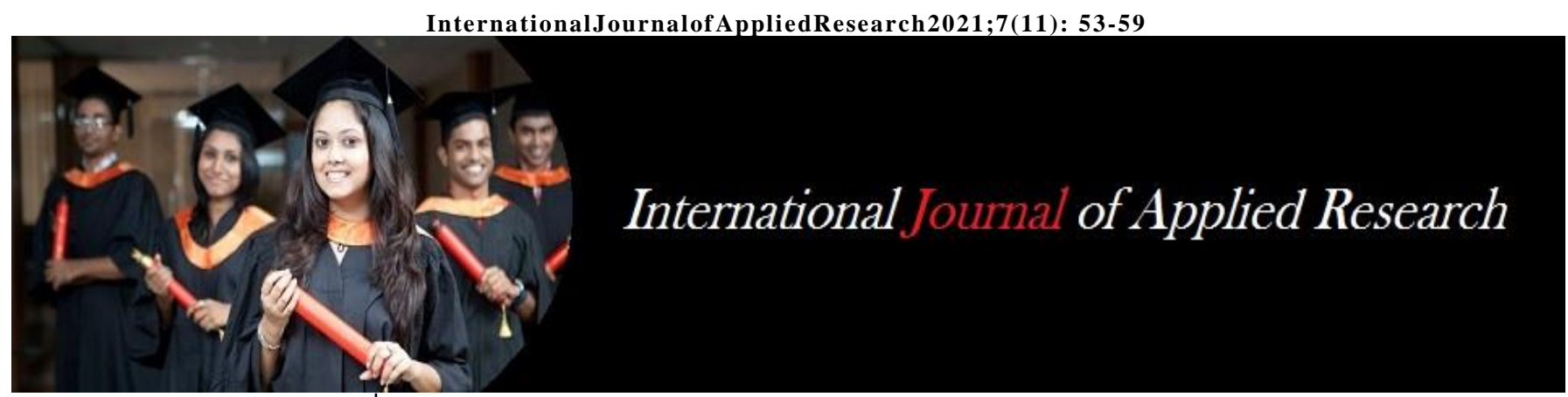

ISSN Print: $2394-7500$ ISSN Online: 2394-5869 Impact Factor: 8.4 IJAR 2021; 7(11): 53-59 www.allresearchjournal.com Received: 02-08-2021 Accepted: 30-09-2021

Dr. Sangeeta Porwal Associate Professor, Dyal Singh College, University of Delhi, New Delhi, India

\section{Relevance of break-even points for start-ups in decision making (Case-based approach)}

\section{Dr. Sangeeta Porwal}

DOI: https://doi.org/10.22271/allresearch.2021.v7.i11a.9101

\section{Abstract}

Young and dynamic entrepreneurs are very much interested in starting up new ventures with new innovative ideas. These new ideas require funding. Every entrepreneur, be it a venture capitalist or a financier, is interested in knowing when a startup will start generating the profits or when there will be a break-even for assessing the viability of the project. Being dynamic in nature, they are interested in knowing when they will get back the funds (fixed cost) invested in the project as soon as possible, so that funds can be spared for another new innovative ideas. It is here the role of break-even analysis comes into existence. Break-even analysis is a management tool to study cost-volume-profit relationship. It is concerned with determining that level of activity where total revenue/sales is equal to total cost in narrower sense. However, its wider interpretation may refer to techniques which determines profit at any level of activity. BEP generates the information that is useful in decision making and profit planning. If sales are not equal to total cost, it cautions management to find cause and take appropriate actions to reduce fixed cost or variable cost. The objective of writing this paper is to develop the understanding how to calculate the different types of Break-even points in different business models and how they are useful in decision making, planning and control. Cases-based on real life situation have been used to explain different types of BEP. The paper will be useful to start-up business and their management in decision making.

Keywords: Break-even point, break-even analysis, cost, decision making, profit planning

\section{Introduction}

Quick decision making is very important especially in today's fast communicating and changing world. For timely decisions one needs to have a correct information very fast. Decisions are based on the bunch of relevant information both quantitative and nonquantitative information. The goal of the company is to become profitable as early as possible, therefore, it is imperative to calculate break-even point of the product or services it caters to know the number of units when it will start earning profit. Break-even point (BEP) provides a quantitative information which is beneficial in taking relevant decisions with other relevant information. BEP is a point where revenue/sales from a business is equal to its total cost i.e., fixed cost and variable cost. It is a point of no loss and no profit.

BEP is very pertinent to describe a start-up firm that is targeting to reach a point of profitability after gestation period losses that are supported by investors or venture capitalists. Cost accountants, management accountants, finance managers and top management use this information in taking various business decisions like applying for loans, fixation of selling prices etc. If revenue/sales are not sufficient to cover up the total cost (both fixed cost and variable cost), one needs to investigate the cause and take appropriate efforts to reduce either fixed cost or variable cost. The objective of writing this paper is to concentrate on how to compute different types of Break-even points and their relevance in decision making. The paper shall be useful to the start-up business, venture capitalist, and financiers in comprehending the concept. The concepts have been explained based on the cases which pertains to the real-life situations. The paper specifically mentions the learning objectives with respect to each type of break-even point.

\section{Review of Literature}

A research study done by Nabil Almassar, Osama Shaban, and Ziad Al Zabi (May 2014) throws light on the reality use of BEP in planning, controlling and decision making in industrial companies of Jordan.
Dr. Sangeeta Porwal Associate Professor, Dyal Singh College, University of Delhi, New Delhi, India

$$
\sim 53^{\sim}
$$


The sample used was 54 employees in accounting departments of Jordanian industrial companies. The outcome of the study was that most of the companies were using BEP as a main tool of decision making, planning and control and have recommended the use of BEP as a main tool of decision making because of its impact, efficiency, and accuracy in the rationalization and control process.

The study conducted by Agus Jamaludin (2019) ${ }^{[2]}$, In their paper titled "Analysis of Break-even Point in CV. Bata Cikarang Indonesia." focuses on finding out the financial performance of CV Bata Cikarang done based on Break Event Point analysis and suggested to use it as a reference in making decisions that affect company's future.

Le, Oanh Thi Tu, Tran, Phong Thi Thu, Tran, Thuan Van, (2020) ${ }^{[4]}$ examined in their paper, titled "Application of Cost-Volume-Profit analysis in Decision-Making by Public Universities in Vietnam", the application of Cost-VolumeProfit analysis by public universities in Vietnam. The results of the study found that the Cost-Volume-Profit analysis is useful in decision making. They also did the Break-even point analysis of various courses offered by universities and how it classifies cost between variable and fixed cost for calculation of BEP. However, the study found the application of CVP analysis by university administrators of decision making was neither comprehensive nor coordinated.

Enkeleda Lulaj, Etem Iseni conducted the research in manufacturing and service enterprises to know how much CVP analysis is used to planning and decisions making in business environment. The results of this research showed that amount of product produced has positive effect on sales value to service companies and raising profit to the manufacturing business environment, also exists an important relationship between production and sales, and CVP analysis contributes to growth profitability and breakeven in the business environment.

\section{Methodology}

The paper highlights the different types of the Break-even points. All these different types of BEPs will help start-ups to estimate the requirement of fixed cost and variable cost.

1. Simple BEP for those start-ups who wants to deal in one type of product only.

2. Composite BEP as a guide to start-ups who wants to produce multiple products.

3. Cash BEP- There is a saying in business "that cash is king”. Start-up should be equipped with cash as and when need arises so that there is no interruption in the smooth functioning of the business.

4. Cost BEP/Cost Indifference Point- When various types of machines available for start up to decide which one to purchase depending the demand in the market.

5. Multiple Break-even Point for the purpose of this paper has been related to life cycle of the product. The first break-even point will arise in the growth stage.

After that company starts earning the profits and profits will increase till the maturity stage. After the maturity stage, profits decline as the product enters in the declining phase and the second break-even point will arise (second breakeven point will arise as the sales price will be reduced to maintain the sales) at that time and company should think of abandoning the product to save it from the losses and fair assessment of the product should be done by evaluating the technology of the product meaning thereby product getting obsolete technology wise.

Each type of BEP is explained and discussed based on the hypothetical case developed by the author.

\section{Simple BEP for those start-ups who wants to deal in one type of product}

It is the point or state of a business at which there is neither profit nor loss. It is computed in the company which is producing and selling only one product or service. The BEP is derived by taking into consideration the relationship among fixed cost, variable cost and sales figure.

Sales $($ Revenue $)=$ Fixed cost + Variable cost + Profit (if any)

Alternatively,

$\{100 *($ Sales - Variable cost $) /$ Sales $\} *($ Sales $)=\{$ Fixed cost + profit (if any) $\} * 100$

Replacing the expression $\{100 *($ Sales-variable cost $) /$ Sales $\}$ as PV (Profit volume) ratio in the above equation

Sales $*$ PV ratio $=\{$ Fixed cost + Profit (if any) $\}$

As sales at BEP, profit would be NIL, it can be expressed as:

Sales at BEP $($ Revenue $)=($ Fixed cost +0$) /$ PV ratio

Simple BEP $=$ Fixed cost $/ \mathrm{PV}$ ratio

Where PV ratio is equal to: $\{($ Sales - Variable cost $) * 100\}$ /Sales

Let us calculate the BEP based on the following example: Selling price per unit Rs. 100, Variable cost per unit Rs. 60, Fixed cost Rs. 1,00,000 inclusive of Rs. 20,000 as depreciation.

Solution:

PV ratio $=$ Sales - Variable cost $/$ Sales $=(100-60) / 100=40 \%$

$\mathrm{BEP}=1,00,000 / 40 \%=$ Rs 25,000 or in units -250 units.

Management of the start-up must consider certain assumptions while finding the situation of no profit or no loss

1. Company is manufacturing and selling one type of product or service.

2. Principle of cost variability must be adhered. Every cost must be separated strictly in two costs i.e., fixed cost and variable cost. Semi-variable (if any) must further be classified as fixed or variable only.

3. Fixed cost must be taken as constant. i.e., they do not change with the changes in the volume.

4. Variable cost that is classified as variable will change in commensurate with volume of output.

5. Selling prices per unit of the product or services is independent of increase or decrease in the number of units.

6. The general price level i.e., inflation will not change during the period considered for analysis. 
7. Sales and the cost related to must belong to the period considered for the analysis.

8. There is a perfect competition in the market for product the company produces, hence company cannot influence the selling price in the market.

9. Efficiency and productivity of the production process and the workers remain unchanged.

Break-even point analysis helps in taking various decisions like

1. Level of sales to earn the desired profit. Hence it is concerned with production planning and profit planning.

2. Break-even point analysis assists in the decisions of classifying the cost in fixed and variable.

3. The analysis also contributes to computation of Shut Down Point when company is not able the cover the fixed cost and variable cost in cash.

4. Break-even point analysis explores the relationship of cost-volume-profit. It visualizes relationship between cost of production, volume of production and the sales value.

5. According to Kohlar, the cost-volume-profit relationship is "area of interest, within an organization, of management and accountants in observing and controlling the relations between prospective and actual manufacturing costs both fixed and variable-rates of production and gross profits". It is very important tool for management control in case start-ups especially in analyzing behavior of fixed cost and variable cost

To sum up, breakeven point analysis is helpful to the startup and management in taking various decisions relating to planning, forecasting, budgeting, and control. It has its own requirements to do Break-even point analysis. These requirements can be taken as its limitations.

\section{Case study}

Let us understand the concept based on a case.

A Youngman Tours and Travel Agency is a new start-up company which organizes the tours to different places in India and abroad. Mr. Suneet, A young senior employee of the company is responsible in organizing the tours in various schools in Delhi. He is in contact with the principal of the school named Eye opener School in Delhi. Principal and Mr. Suneet both are willing to take the students of the school to a hill station in India. Mr. Suneet has submitted following details to the principal of the school.

The school is ready to provide around150 students for touring at the hill station based on the verbal consent given by the students. However, final consent is to be obtained from the parents. Agency is likely to hire 5 buses (depending upon the number of students) at aren't of Rs 60,000 per bus per day basis for taking students at various places. The bus capacity is 30 students excluding two seats reserved for staff (an attendant and a teacher for every bus hired depending upon the number of students).

During the stay of four days, various activities will include:

1. Planetarium charges for all the students (Block entrance) - Rs 22,000.

2. Three games will be played among students and the best student will be paid prizes Rs 2000 for each game.

3. Skating charges for all students (Block entrance) - Rs 45,000.

4. Water Park Entrance fee for all students - Rs 90,000

5. Amusement Park Entrance fee for all students - Rs. 75,000

6. Meal charges:

a. Break Fast - Rs 100 per student/per day

b. Lunch and dinner - Rs 400 per student/per day

c. Tea - Rs 50/per student/day

7. School proposes to charge fixed commission of Rs. 50,000 from Agency since it is proposing the business to the agency. However, no Commission would be charged if number of students is less than 100.

8. There is a contractual agreement of the Agency from the hotel at the hill station to charge fixed amount of Rs. 6,00,000 up to 100 students for 4 days. However, if number of students exceeds 100 , excessive charges of Rs 500 per student per day will be charged.

9. Each teacher would be paid allowances Rs. 400 per day and each attendant would be paid half of the amount teachers allowance on per day basis.

To make rational decision, management of the start-up must prepare various statement like

1. Budget estimate of the total cost for the levels of 90 , 120, and 150 students.

2. Proper classification of fixed cost, variable cost, and semi-variable cost and how to treat the semi variable cost.

3. Average cost per student at various levels.

4. Number of students to Break-even if school proposes to collect Rs. 12,200 per student.

Table 1: Showing budget estimate of the total cost

\begin{tabular}{|c|c|c|c|}
\hline \multicolumn{5}{|c|}{ Budget estimate of the total cost } \\
\hline Level of the students (No.) & 90 & 120 & 150 \\
\hline & Rs. & Rs. & Rs. \\
\hline \multicolumn{5}{|c|}{ Mariable cost } \\
\hline \multicolumn{5}{|c|}{ Meal charges } \\
\hline Lunch/Dinner @ Rs 400 & $(400 * 4 * 90)=144,000$ & $(400 * 4 * 120)=192000$ & $(400 * 4 * 150)=2,40,000$ \\
\hline$(400 * 4 * 90)=144,000$ & $(100 * 4 * 90)=36,000$ & $(100 * 4 * 120)=48,000$ & $(100 * 4 * 150)=60,000$ \\
\hline$(400 * 4 * 120)=192000$ & $(50 * 4 * 90)=18,000$ & $(50 * 4 * 120)=24,000$ & $(50 * 4 * 150)=30,000$ \\
\hline Total VC & $1,98,000$ & $2,64,000$ & $3,30,000$ \\
\hline \multicolumn{7}{|c|}{ Fixed cost } \\
\hline Planetarium charges & $22,000 \quad 22,000$ & 22,000 \\
\hline Prizes to students & 6,000 & 6,000 & 6,000 \\
\hline Skating charges & 45,000 & 45,000 & 45,000 \\
\hline Water park fee & 90,000 & 90,000 & 90,000 \\
\hline Amusement park fee & 75,000 & 75,000 & 75,000 \\
\hline Total fixed cost & $2,38,000$ & $2,38,000$ & $2,38,000$ \\
\hline
\end{tabular}




\begin{tabular}{|c|c|c|c|}
\hline \multicolumn{4}{|c|}{ Semi-variable cost } \\
\hline Commission to school & ---- & 50,000 & 50,000 \\
\hline \multicolumn{4}{|c|}{ Allowances } \\
\hline Attendant & 2400 & 3200 & 4000 \\
\hline Teachers & 4800 & 6400 & 8000 \\
\hline Bus charges & $1,80,000$ & $2,40,000$ & $3,00,000$ \\
\hline \multirow{2}{*}{ Staying charges } & $6,00,000$ & $6,40,000$ & $7,00,000$ \\
\hline & $(600000+500 * 4 * 20)$ & $(600000 * 500 * 4 * 50)$ & \\
\hline Total cost & $7,87,200$ & $9,39,600$ & $10,62,000$ \\
\hline \multirow{3}{*}{ Average cost per student } & $12,23,200$ & $14,41,600$ & $16,30,000$ \\
\hline & $12,23,200 / 90$ & $14,41,600 / 120$ & $16,30,000 / 150$ \\
\hline & $=13591.11$ & $=12013$ & $=10866$ \\
\hline \multicolumn{4}{|c|}{ Computation of BEP } \\
\hline Collection per student & $=$ Rs 12,200 & & \\
\hline VC/student - & Rs 2200 & & \\
\hline Contribution per student & Rs 10,000 & & \\
\hline Total $(\mathrm{FC}+$ Semi VC) & Rs $10,25,200$ & $11,77,600$ & $13,00,000$ \\
\hline \multirow[t]{2}{*}{$\mathrm{BEP}$} & $10,25,200 / 10,000$ & $11,77,600 / 10000$ & $13,00,000 / 10000$ \\
\hline & $=102.52$ & $=117.76$ & $=130$ \\
\hline
\end{tabular}

Interpretation: How many buses are to be hired depends on the number of students. If 150 students are willing to go, hiring 5 buses is profitable. The Break-even number of the students is 130 students. Therefore, any number of the students above 130 would start contributing to profits. Carrying 150 will be most profitable.

However, Agency may choose to hire four buses as BEP is 118 students. Four buses can take only 120 students. Therefore, only two students will contribute to profits. If there is no profit or loss, agency should also consider the acceptance of proposal based on other Non-financial factors in taking the decision. Such factors can be establishing relationship with the school for future business, building goodwill of the agency in other schools to grab business in other schools. etc.

Variable cost remains the same irrespective of number of students. But the average cost per students will reduce when number of students increase, as can be seen above in the statement.

Having done real life situation case study, the learning objectives that the start-ups are expected to understand the cost classification between fixed and variable cost. They should know how to identify the variable and fixed cost. They should know how to calculate the Break-even Point in real-life situation and its usefulness in decision making and profit planning.

Composite BEP as a guide to start-ups producing multiple products

Composite BEP helps the management to decide how many units of each product can be produced and then the management must see their production capacity and demand in the market. Accordingly, the management decides about the various investments.

Composite BEP $($ Sales revenue $)=($ Total fixed costs/Composite PV ratio) * 100

Where Composite PV ratio $=\{($ Total Sales - Total variable costs) $* 100\} /$ Total sales. Let us understand the concept with an example.

A company produces and sells four varieties of products A, B, C, and D, which are produced and sold under the supervision of four different managers respectively. Their composition of sales is in the proportion of $40 \%, 30 \%, 20 \%$, and $10 \%$ of $\mathrm{A}, \mathrm{B}, \mathrm{C}$, and $\mathrm{D}$ respectively. The Total sales are likely to be Rs. 1,00,000 per month. Total fixed cost is likely to Rs. 20,000 . The operating cost of each product is $50 \%, 70 \%, 80 \%$ and $30 \%$ based on its share in sales value of total sales.

\section{Solution}

Table 2: Depicting calculation of operating cost

\begin{tabular}{|c|c|c|}
\hline & Sale value (Rs) & Operating cost (Rs) \\
\hline $\mathrm{A}=1,00,000 * 40 \%$ & 40,000 & $40,000 * 50 \%=20,000$ \\
\hline $\mathrm{B}=1,00,000 * 30 \%$ & 30,000 & $30,000 * 70 \%=21,000$ \\
\hline $\mathrm{C}=1,00,000 * 20 \%$ & 20,000 & $20,000 * 80 \%=16,000$ \\
\hline $\mathrm{D}=1,00,000 * 10 \%$ & 10,000 & $10,000 * 30 \%=3000$ \\
\hline \multicolumn{3}{|c|}{ Total variable cost $=$ Rs60000 } \\
\hline Composite PV ratio & $=(1,00,000-60,000)$ & $1,00,000=40 \%$ \\
\hline Composite BEP & $=(20,000 / 40 \%)$ & $=$ Rs. 50,000 \\
\hline \multicolumn{3}{|c|}{ Share of sale of each product in the composite BEP } \\
\hline \multicolumn{3}{|c|}{$\mathrm{A}=50,000 * 40 \%=20,000, \mathrm{~B}=50,000 * 30 \%=15,000, \mathrm{C}=50,000 * 20 \%=10000, \mathrm{D}=50,000 * 10 \%=5,000$} \\
\hline
\end{tabular}

Managers of each product must strive to achieve his product share. This is dependent on the demand of the products. Start-ups must consider certain assumptions/requirements while calculating composite BEP.
1. Firm must produce and sell multiple products and their sales mix remain constant.

2. All products are manufactured under the same facility under common administrative machinery. 
3. Fixed costs are joint costs which are allocated among the products in the budgeted sales volume.

4. Other assumptions/requirements are same as mentioned in case of simple BEP from 2 to 9.

This analysis helps star-ups in taking various decisions like

1. Managers can identify the most profitable product and thereby increase the production and its sales subject to the visualization of overall goals of the company and demand of the product in the market.

2. It brings about cooperation and coordination among the managers who are supervising these different products. It brings about sense of belongingness as they are part of decision-making process.

\section{Cash BEP to see the liquidity}

It is that level of activity where cash inflows from sales or output are just equal to meet cash costs, which means there is no cash profit and no cash loss. For computing cash BEP, Fixed costs are divided in two parts. 1. Cash fixed costs and 2. Non-Cash fixed costs. The cash fixed costs require immediate payment in cash. Hence, there is an immediate outflow of cash for example, Payment of rent, insurance, and salary of the permanent staff etc.; 2. Non-Cash fixed costs do not require immediate outflow/payment of cash. For example, charging depreciation on Fixed assets (i.e., plant and machinery, building etc.,).

Cash BEP $=($ Cash fixed costs $/ \mathrm{PV}$ ratio $) * 100$

We have computed cash BEP based on the figures given in example above (Simple BEP). Accordingly, depreciation has been deducted from the fixed cost.

Cash BEP $=80,000 / 40 \%=$ Rs. 20,000 or 200 units.

Assumptions and requirements in computing cash BEP are the same as in case of Simple BEP, except cash fixed costs are to be considered

1. Cash BEP is useful in assessing the liquidity position of the company.

2. It is useful in conducting budgeting process of the company.

3. It is helpful especially to start-up companies in assessing the availability of cash for payment of loans (i.e., principal amount and interest on the loan amount).

\section{Cost BEP/Cost Indifference Point}

Cost BEP is discussed under two situations:

(i) When only two models of machines are available:

It is a situation where total cost of operating two machines or two alternatives are equal. Both the machines/alternative may have the same total costs. Their total fixed cost and variable cost/unit may be different. For example, a company wants to buy Semi-automatic machine vs. fully automatic machine for manufacturing potato chips. Another example could be given is of that company wants to install washers and dryers machine in various colonies in the city. There are two options/alternatives for the company to buy fully automatic machine or partly automatic machines. The cost
BEP assist in deciding which alternatives we go for a given level of output.

Total cost of machine 1 at BEP (units) $=$ Fixed cost of machine $1+$ Variable cost/unit of machine $1 * \mathrm{Y}$ units

Total cost of machine 2 at BEP (units) $=$ Fixed cost of machine $2+$ variable cost/unit of machine $2 *$ y units

Since the total cost of both the machines is equal as per definition of cost BEP given above, we can equate the two equations given above to calculate the $\mathrm{y}$ units (where cost for both the plants would be equal).

Cost BEP in units $\mathrm{Y}=$ (Differential fixed cost in machines $) /$ (Differential variable cost/unit in machines)

An example in this respect is as follows:

Table 3: Showing cost details of two machines

\begin{tabular}{|c|c|c|}
\hline & Machine 1 & Machine 2 \\
\hline Fixed cost (Rs.) & $1,00,000$ & 50,000 \\
\hline Variable cost per unit (Rs.) & 30 & 40 \\
\hline
\end{tabular}

\section{Solution}

Assumption: Fixed cost for the fully automatic machine would be higher than semi-automatic machine. Variable cost /unit will be lower in case of the fully automatic than the semi-automatic machine.

$$
\text { Cost } \mathrm{BEP}=50,000 / 10=\text { Rs. } 5,000 \text { units }
$$

Total cost of machine 1 at BEP (units) $=1,00,000+$ $5,000 * 30=$ Rs $2,50,000$

Total cost of machine 2 at BEP (units) $=50,000+5,000 * 40$ $=$ Rs 2,50,000

Interpretation: If demand of the product in terms of units is higher than the Cost BEP (units), one should go for automatic, otherwise (demand of units is lower than cost BEP (units), one should go for the semi-automatic machine. However non-financial factors must be taken into consideration.

Having background under which situation cost BEP is useful in decision making, let us discuss a small case to understand the concept and its application in the real-lifesituation.

\section{Case study}

A practicing lawyer is residing in Delhi city. He travels a lot for his practice in the city to meet the clients and to represent the cases in the courts. For this purpose, he is travelling in either in the public transport or taxies for which heavy fares are being paid by him. He has two options/alternatives with him. He is thinking of buying a new small car having automatic gears or old bigger car manual gears. Following details are available (estimated) about the two options. 
Table 4: Portraying estimated details of two options

\begin{tabular}{|c|c|c|}
\hline & New car automatic Rs. & Old bigger manual Rs. \\
\hline Purchas price & $6,00,000$ & $3,00,000$ \\
\hline Sale price after 5 years & $2,00,000$ & $1,00,000$ \\
\hline Repairs per annum & 2,000 & 10,000 \\
\hline Tervicing (done the basis of fixed time period) & 5,000 & 2,000 \\
\hline \multicolumn{2}{|c|}{ Per annum } & 1,000 \\
\hline Tnsurance per annum & 2,000 & 3,000 \\
\hline Petrol consumption (Kms per litre) & 20,000 & $10 \mathrm{kms}$ \\
\hline Petro price/litre & $20 \mathrm{kms}$ & Rs. 100/litre \\
\hline
\end{tabular}

Repairs, servicing, taxes, insurance, and depreciation are to be taken as fixed costs.

Based on the past experiences, he is likely to travels 10,000 kms.

1. Lawyer is interested in knowing, which one of the two options, he should select travelling 10,000 kms.
2. Lawyer is willing to expands his practice and plans to travel 20,000 kms, which option should he select?

3. Lawyer is also interested in knowing a point in Kilo meters, where cost under both options would be the same.

Table 5: Showing cost statement of the two options

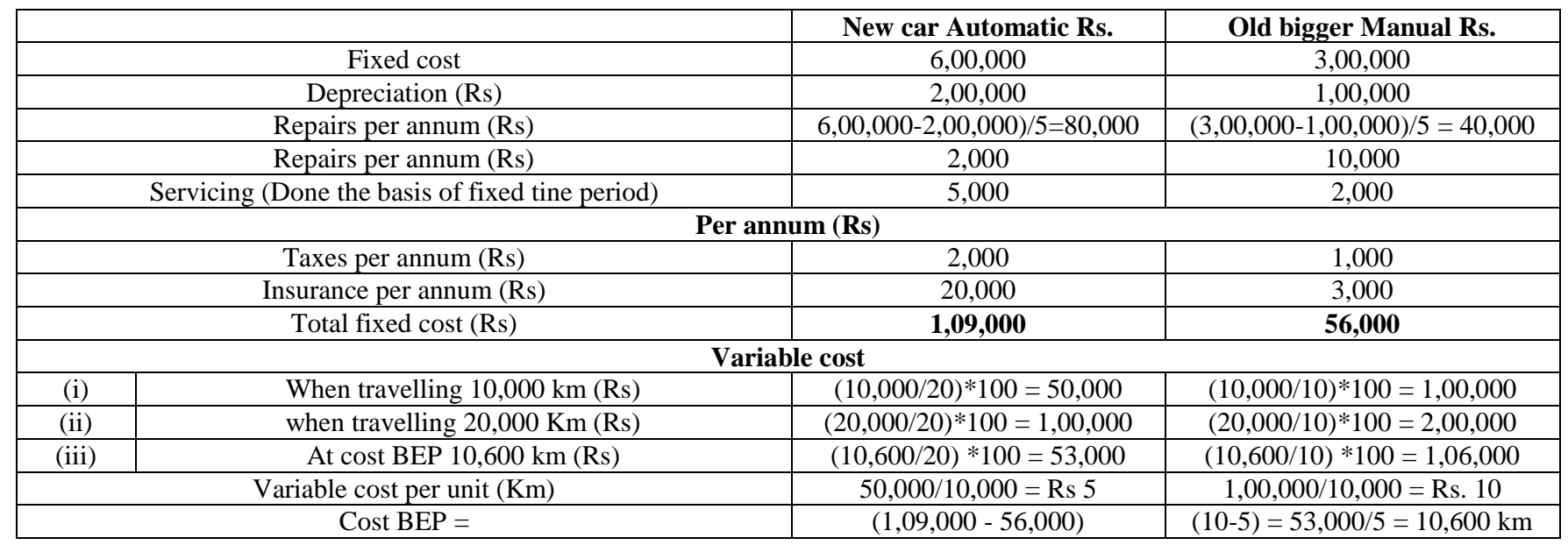

Interpretation: As can be seen at cost BEP of 10,600 km total cost in both the cars is the same, if lawyer expands his practice travelling more the cost BEP, New automatic car will be economical. If lawyer expands his practice but travels below Cost BEP, Old car would be economical.
Mr. Ramesh is willing to invest to produce product ' $\mathrm{P}$ '. However, he is confused which machine he should buy.

Following are the cost estimates of three prospective machines $\mathrm{X}, \mathrm{Y}$, and $\mathrm{Z}$ :

The same product $(\mathrm{P})$ is produced on these machines having same quality having unit selling price of Rs. 8 per unit.

(II) When three variants of machine are available:

Table 6: Showing cost details of the three machines $\mathrm{X}, \mathrm{Y}$, and $\mathrm{Z}$

\begin{tabular}{|c|c|c|c|}
\hline & Machine X & Machine Y & Machine Z \\
\hline Annual capacity (units) & 75,000 & $1,20,000$ & $1,50,000$ \\
\hline Annual fixed cost per unit (Rs.) & $1,20,000$ & $2,16,00$ & $2,40,000$ \\
\hline Variable cost per unit (Rs.) & 5 & 4.40 & 4.20 \\
\hline
\end{tabular}

1. Ramesh wants to know the range of output over which each of the Machine would be economical.

2. If sales are 1,00,000 units per year, what will be profits earned with each of the machines on the assumption Machine $X$ can be worked double shift with an additional expense of $5 \%$ in variable cost of all units and $15 \%$ in fixed costs.

For finding the range of output over which each of the machine would be most economical, following statement can be made:

Table 7: Showing computation of profit for three machines $\mathrm{X}, \mathrm{Y}$, and $\mathrm{Z}$

\begin{tabular}{|c|c|c|c|}
\hline & Machine X & Machine Y & Machine Z \\
\hline Selling price per unit & 8 & 8 & 8 \\
\hline Variable cost per unit & 5 & 4.40 & 4.20 \\
\hline Contribution per unit & 3 & 3.60 & 3.80 \\
\hline Annual fixed costs & $1,20,000$ & $2,16,000$ & $2,40,000$ \\
\hline BEP (units) & $1,20,000 / 3$ & $2,16,000 / 3.6$ & $2,40,000 / 3.8$ \\
\hline
\end{tabular}




\begin{tabular}{|c|c|c|c|}
\hline Economical range of output & $=40,000$ & $=60,000$ & $=63,158$ \\
\hline & 40,001 to 75,000 & 60,000 to $1,20,000$ & 63,158 to $1,50,000$ \\
\hline Statement of profits when sale is 100000 units & Machine X & Machine Y & Machine Z \\
\hline Contribution per unit & $3-0.25=2.75$ & 3.60 & 3.80 \\
\hline Total contribution on $1,00,000$ units & $2,75,000$ & $3,60,000$ & $3,80,000$ \\
\hline Less: fixed cost & $1,20,000+15 \%$ & $2,16,000$ & $2,40,000=1,38,000$ \\
\hline Profit & $1,37,000$ & $1,44,000$ & $1,40,000$ \\
\hline
\end{tabular}

Based on the economical range of output, Mr. Ramesh can decide which machine is most profitable. Buying Machine $\mathrm{Y}$ is most profitable. However, non-financial factors (i.e., demand of the product in the future) should also be considered by Mr. Ramesh.

\section{Multiple BEP in real-life situation}

Can we have multiple BEP with respect to one product?

Answer is yes. We will discuss Multiple BEP with reference to startup companies. Multiple BEP and Composite BEP are different. Composite BEP is a situation where a company produces number of products (already explained above).

BEP is computed on the assumption that variable cost per unit and selling price per unit will remain the same. It is for this reason, the relationship between cost line and revenue line is linear. But in actual situation, it may take non-linear shape if price is reduced to increase the sale. Similarly, cost line can also take non-linear shape because of economies of scale. The concept can be attributed to newly formed/startup companies with the product they produce.

Lately, the world is facing Corona Crisis. Recently in India, new daring and budding entrepreneurs are coming with new ideas and new innovative products. New and start-up companies are floated in the market now and then. It becomes very imperative for them to understand the mechanics of cost per unit, selling price per unit and the volume of the product in which they deal. This requires comprehending the concept of Break-even point and use it as management tool for decision making and profit planning. It is very quintessential for investors and new entrepreneurs to classify the cost into fixed and the variable to calculate the Break-even point. An in-depth analysis of all costs is to be done before starting the new venture in conjecturing the number of units that will be required for break-even. After maturity stage of the life cycle of the product, to increase the sales, price is reduced. Likewise, to take advantage of economies of the scale, cost goes down, as a result the cost line and the revenue line becomes curvilinear. Hence Break-even points arise. If this happens, it is warning signal about the maturity of the product and therefore, one should think about the innovation of the existing product/or entirely new product/diversification to remain in the business. Here comes the concept of life-cycle costing. The investors, venture capitalist and managers will have to guess/forecast the life of the product properly. Because of new innovative ideas that are emerging very fast in this changing world, product becomes obsolete faster than its estimated life.

\section{Suggestions}

1. Entrepreneurs, venture capitalist, financiers etc., will have to be very careful in estimating the life of the product before it becomes obsolete because of changing technology.

2. They must forecast when new business will start generating profits and hence it is imperative to know in advance the Break-even point of the new start up. This is very essential for taking the decision with respect to budgeting process, profit planning and control purpose.

3. Proper classification of fixed cost and variable cost is important with minute details before starting the new business.

\section{References}

1. Nabil Almassar, Osama Shaban, Ziad Al Zabi. Effect of Using Break-Even-Point in Planning, Controlling, and Decision Making in the Industrial Jordanian Companies. International Journal of Academic Research in Business and Social Sciences 2014. http://dx.doi.org/10.6007/IJARBSS/v4-i5/888.

2. Agus Jamaludin. Analysis of Break-even Point in CV. Bata Chikarang Indonesia. International Journal of Research - Granthaalayah 2019;7(9):259-267. https://doi.org/10.29121/granthaalayah.v7.i9.2019.609.

3. Enkeleda Lulaj, Etem Iseni. The Role of CVP Analysis as Important Indicator in Planning and Decision Making in Business Environment. European Journal of Economics and Business Studies, May-August 2018;4(2):99. ISSN 2411-9571 (Print) ISSN 2411-4073 (online) 99. DOI: 10.26417/ejes.v4i2.p99-114

4. Le Oanh Thi Tu, Tran Phong Thi Thu, Tran Thuan Van. Application of Cost-Volume-Profit Analysis in Decision-Making by Public Universities in Vietnam. The Journal of Asian Finance, Economics, and Business 2020, 305-315, 2288-4637. PIssn, eISSN 2288-4645. https://doi.org/10.13106/jafeb. 2020;7(6):305. ISSN 2411-9571 (Print). ISSN 2411-4073 (online) 99. DOI: 10.26417/ejes.v4i2.p99-114

5. Garrison Ray, Noreen, Eric, Brewer, Peter. Managerial Accounting, 14th Ed. McGraw-Hill Irwin 2011.

6. Horngren, Charels Datar T, Srikant Rajan M, Madhav V. Cost Accounting 14th Ed. Pearson Education Limited 2014.

7. Moyer McGuigan, Kretlow. Contemporary Financial Management, 10th, Tenth Edition. South Western Publishers 2005.

8. Needles, Belverd E, Powers Marian, Mills Sherry K, Anderson Henry R. Principles of Accounting. 7th ed. Houghton Mifflin 1999.

9. Arora MN. Text book of Cost and Management Accounting. Vikas Publishing House Pvt. Limited, $10^{\text {th }}$ Edition.

10. Maheswari and Mittal. Cost Accounting Theory and Problems. Shri Mahavir Book Depot (Publisher), $26^{\text {th }}$ Edition. 